This item was submitted to Loughborough's Research Repository by the author.

Items in Figshare are protected by copyright, with all rights reserved, unless otherwise indicated.

\title{
Permeability enhancement for transdermal delivery of large molecule using low frequency sonophoresis combined with microneedles
}

PLEASE CITE THE PUBLISHED VERSION

http://www.ukpharmsci.org/default.asp

\section{PUBLISHER}

(C) the authors, Academy of Pharmaceutical Sciences of Great Britain

\section{VERSION}

AM (Accepted Manuscript)

\section{PUBLISHER STATEMENT}

This work is made available according to the conditions of the Creative Commons Attribution-NonCommercialNoDerivatives 4.0 International (CC BY-NC-ND 4.0) licence. Full details of this licence are available at: https://creativecommons.org/licenses/by-nc-nd/4.0/

\section{LICENCE}

CC BY-NC-ND 4.0

\section{REPOSITORY RECORD}

Han, Tao, and Diganta Bhusan Das. 2015. "Permeability Enhancement for Transdermal Delivery of Large Molecule Using Low Frequency Sonophoresis Combined with Microneedles". figshare. https://hdl.handle.net/2134/18570. 


\title{
Permeability enhancement for transdermal delivery of large molecule using low frequency sonophoresis combined with microneedles
}

\author{
T. Han, D.B. Das \\ Department of Chemical Engineering, Loughborough University, Loughborough, UK.
}

\section{INTRODUCTION}

Transdermal drug delivery intends to deliver drug molecules to the blood circulation via percutaneous absorption. However, it is limited by the high resistance of skin towards diffusion of high molecular weight drugs. This is mainly due to the fact that the outer layer of the skin, i.e., the stratum corneum (SC), can prevent diffusion of molecules whose molecular weight is greater than $500 \mathrm{Da}$ [1]. Researches on large molecules delivery become more active and various technologies have been applied to conquer this problem. However, there is no technology can provide satisfactory permeability thereby the problem is still unsolved. The two technologies we used are: (i) sonophoresis which involves use of ultrasound generated cavitation to enhance the permeability of the skin [2]; (ii) microneedles which is used to create micro-cavities in skin while provide painless administration [3]. We report a novel way to combine microneedles with ultrasound. The solid microneedles can create a good porous basis on the skin. It weakens the resistance of the SC layer and exposes parts of the underneath epidermis to the molecule of interest. The ultrasound treatment is then applied on the microneedles pre-treated area to further enhance the skin permeability [4].

\section{MATERIALS AND METHODS}

All diffusion experiments are conducted using a Franz diffusion cell system which is commonly used for measuring drug permeability in skin. It was used in this work to determine the permeability. It is consisted of four parts: the water tank, the heater, the magnetic plate and the diffusion cells which are shown in Fig.1.
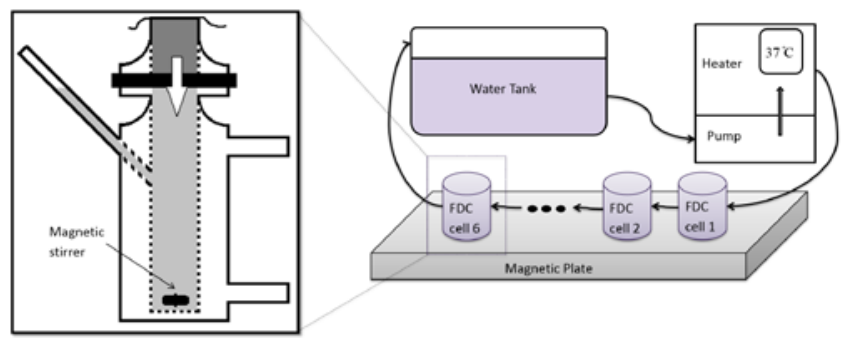

Fig. 1 The full setup of the Franz diffusion cells system. The four components of the system are marked in the picture.

\section{RESULTS AND DISCUSSION}

In all the diffusion experiment, bovine serum albumin (BSA) is used as a model of large molecule. Our results show that the permeability of BSA is increased to $1 \mu \mathrm{m} / \mathrm{s}$ (Fig.5) with the combination of $1.5 \mathrm{~mm}$ microneedles patch and $15 \mathrm{~W}$ ultrasound output which is about ten times higher than the permeability obtained in passive diffusion (Fig.2). Diffusion with only microneedles or ultrasound pretreatment is also tested. The maximum permeability from microneedles (Fig.4) and ultrasound treatment (Fig.3) reached $0.43 \mu \mathrm{m} / \mathrm{s}$ and $0.4 \mu \mathrm{m} / \mathrm{s}$, respectively.

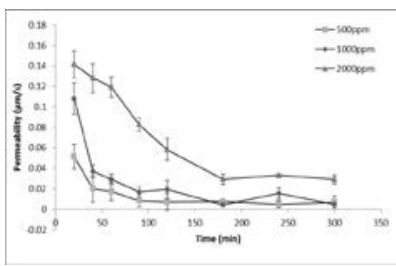

Fig.2 Passive diffusion with different BSA concentrations of $500 \mathrm{ppm}, 1000 \mathrm{ppm}$ and 2000 ppm (results represent mean \pm SD values based on data from 6 skin samples)

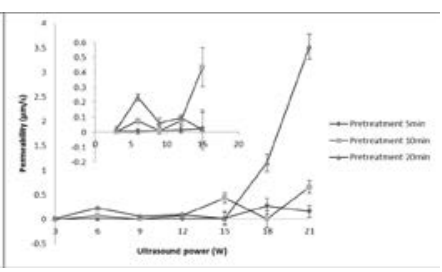

Fig.3 Sonophoresis effect with different power output from $3 \mathrm{~W}$ to $21 \mathrm{~W}$ and pre-treatment time at $5 \mathrm{~min}, 10 \mathrm{~min}$ and $20 \mathrm{~min}$ (results represent mean \pm SD values based on data from 6 skin samples).

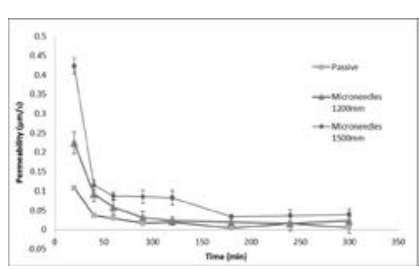

Fig.4 Microneedles pre-treatment for $10 \mathrm{~min}$ (results represent mean \pm SD values based on data from 6 skin samples).

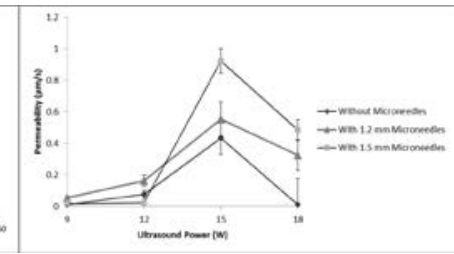

Fig.5 Different ultrasound output power with 10 min treatment time combined with $1.2 \mathrm{~mm}$ and 1.5 mm microneedles patch (results on data from 6 skin samples). represent mean \pm SD values based

\section{CONCLUSIONS}

The idea of combining sonophoresis with microneedles patch provides a feasible way for the delivery of large molecules. The permeability of BSA, which has a relatively large molecular weight, is proved to be significantly increased as shown in this study. It also indicates the possibility of transporting large molecules through human skin in future. The combination of microneedles patch and ultrasound may become a painless alternative to the hypodermal injections for delivering large molecules.

\section{REFERENCES}

[1] M.B. Brown, G.P. Martin, S.A. Jones and F.K. Akomeah, "Dermal and Transdermal drug delivery systems: current and future aspects” Drug Deliv., 13 (2006) 175-187.

[2] B.E. Polat, D Hart, R Langer and D Blankschtein, "Ultrasoundmediated transdermal drug delivery: Mechanisms, scope, and emerging trends” J. Control. Release, 152 (2011) 330 - 348.

[3] H.S. Gill, D.D. Denson, B.A. Burris and M.R. Prausnitz, "Effect of microneedle design on pain in human volunteers" Clin. J. Pain., 24 (2008) 585-594.

[4] T. Han and D.B. Das, "Permeability enhancement for transdermal delivery of large molecule using low frequency sonophoresis combined with microneedles” J. Pharm. Sci., 102 (2013) 3614-3622. 